\title{
Leaf-templated synthesis of 3D hierarchical porous cobalt oxide nanostructure as direct electrochemical biosensing interface with enhanced electrocatalysis
}

\author{
Lei Han ${ }^{\mathrm{a}, \mathrm{b}}$, Da-Peng Yang ${ }^{\mathrm{a}, *}$, Aihua Liu ${ }^{\mathrm{a}, \mathrm{b}, *}$ \\ ${ }^{a}$ Laboratory for Biosensing, Qingdao Institute of Bioenergy \& Bioprocess Technology, and Key Laboratory of Biofuels, Chinese Academy of Sciences, \\ 189 Songling Road, Qingdao 266101, China \\ ${ }^{\mathrm{b}}$ University of Chinese Academy of Sciences, 19A Yuquan Road, Beijing 100049, China
}

\section{A R T I C L E I N F O}

\section{Article history:}

Received 25 April 2014

Received in revised form 4 July 2014

Accepted 8 July 2014

Available online 19 July 2014

\section{Keywords:}

Biomimetic synthesis

Biomineralization

Leaf template

Hierarchical porous cobalt oxide

architecture

Nonenzymatic glucose sensor

\begin{abstract}
A B S T R A C T
A novel three-dimensional (3D) hierarchical porous cobalt oxide $\left(\mathrm{CO}_{3} \mathrm{O}_{4}\right)$ architecture was first synthesized through a simple, cost-effective and environmentally friendly leaf-templated strategy. The $\mathrm{CO}_{3} \mathrm{O}_{4}$ nanoparticles (30-100 nm) with irregular shapes were interconnected with each other to form a 3D multilayer porous network structure, which provided high specific surface area and numerous electrocatalytic active sites. Subsequently, $\mathrm{CO}_{3} \mathrm{O}_{4}$ was successfully utilized as direct electrochemical sensing interface for non-enzymatic detection of $\mathrm{H}_{2} \mathrm{O}_{2}$ and glucose. By using chronoamperometry, the current response of the sensor at $+0.31 \mathrm{~V}$ was linear with $\mathrm{H}_{2} \mathrm{O}_{2}$ concentration within $0.4-200 \mu \mathrm{M}$ with a low limit of detection (LOD) of $0.24 \mu \mathrm{M}(\mathrm{S} / \mathrm{N}=3)$ and a high sensitivity of $389.7 \mu \mathrm{A} \mathrm{mM} \mathrm{mm}^{-1} \mathrm{~cm}^{-2}$. Two linear ranges of $1-300 \mu \mathrm{M}$ (with LOD of $0.1 \mu \mathrm{M}$ and sensitivity of $471.5 \mu \mathrm{A} \mathrm{mM}{ }^{-1} \mathrm{~cm}^{-2}$ ) and $4-12.5 \mathrm{mM}$ were found at $+0.59 \mathrm{~V}$ for glucose. In addition, the as-prepared sensor showed excellent stability and anti-interference performance for possible interferents such as ascorbic acid, uric acid, dopamine, acetaminophen and especially $0.15 \mathrm{M}$ chloride ions. Similarly, other various metal oxide nanostructures may be also prepared using this similar strategy for possible applications in catalysis, electrochemical sensors, and fuel cells.
\end{abstract}

(c) 2014 Elsevier B.V. All rights reserved.

\section{Introduction}

Recently, functional nanostructured or nano-composited metal oxides continued to receive great attention due to their outstanding physicochemical properties such as high specific surface area, excellent semi-conductivity, enhanced electrocatalysis and good biocompatibility, which can be found a wide range of applications in sensing (Zamborini et al., 2011; Hayat and Andreescu, 2013; Liu et al., 2013a, 2013b), energy storage (Jiang et al., 2012; Meyer et al., 2012), field-effect transistor (Ferain et al., 2011) and catalysis (Wei and Wang, 2013; Lin et al., 2014). Particularly, the progress in creating novel nanoscale materials has pushed on the rapid development of analytical chemistry to meet the increasing demands in improving the response time,

\footnotetext{
* Corresponding authors at: Chinese Academy of Sciences, Qingdao Institute of Bioenergy and Bioprocess Technology, and Key Laboratory of Biofuels, Laboratory for Biosensing, 189 Songling Road, Qingdao 266101, China. Tel.: +865328066 2758; fax: +865328066 2778 .

E-mail addresses: liuah@qibebt.ac.cn (A. Liu), yangdp@qibebt.ac.cn (D.-P. Yang).
}

sensitivity, selectivity, and stability (Liu et al., 2005, 2006; Liu, 2008; Soleymani et al., 2009; Solanki et al., 2011). To date, various synthesis strategies of the nanomaterials had been adopted, such as solvothermal synthesis (Mai et al., 2011), sol-gel method (Debecker and Mutin, 2012), electrospinning method (Liu et al., 2004) and lithography technique (Cen et al., 2009). However, these strategies generally require complex technologies, expensive equipments and harmful organic reagents or surfactants, which might further hinder their application. Hence, it is highly desirable to explore facile synthesis strategies which are cost-effective, simple and environmentally friendly to get "green" nanomaterials. To address this issue, one alternative approach is to learn from nature. The magical nature offers us an enormous library of micro/ nano-structured biomaterials with complex morphology, porous structures as well as special functionality. This has stimulated scientists to draw more and more inspiration to take advantage of the intrinsic structures of biomaterials and consider them as templates for fabricating micro/nano-structures conveniently (Sotiropoulou et al., 2008; Jones et al., 2011). Among these biotemplates, DNAs (Berti and Burley, 2008), peptides (Chen and Rosi, 
2010), proteins (Katz and Willner, 2004; Dickerson et al., 2008), viruses (Dujardin et al., 2003; Knez et al., 2003; Nam et al., 2006), bacteria (Berry et al., 2005), diatoms (Rosi et al., 2004), and butterfly wings (Huang et al., 2006) have been explored because of their morphologically complex architectures. However, these biomolecules and organisms are either expensive or insufficient as sources for the large-scale production. In contrast, the leaves are cheap, reproducible and abundant biomass, which can be used for scale-up production of biotemplated materials. Meanwhile, leaves exhibit excellent light-harvesting efficiency because of the 3D architecture of the highly interconnected, nano-layered thylakoid membranes at the nanoscale (Shimoni et al., 2005), and the porous framework of veins at the micrometer (Zhou et al., 2010). These interesting morphologies and characteristics had stimulated researchers to fabricate leaf-templated magnetic iron carbide $\left(\mathrm{Fe}_{3} \mathrm{C}\right)$, titanium dioxide $\left(\mathrm{TiO}_{2}\right)$, magnesium oxide $(\mathrm{MgO})$, platinum $(\mathrm{Pt})$ and silver (Ag) micro/nanomaterials, which are applied to the field of electrodes (Schnepp et al., 2010), photocatalysts (Li et al., 2009; Zhou et al., 2010), water purification (Yang et al., 2013) and antimicrobials (Huang et al., 2011). These materials exhibited many unusual properties. For example, the artificial $\mathrm{TiO}_{2}$ "leaf" was demonstrated to carry higher light-harvesting performance and photocatalytic activity than those prepared with classic routes $^{16}$. The leaf-templated $\mathrm{MgO}$ has the enhanced charged property and adsorption capacity for dye (Yang et al., 2013). The magnetic $\mathrm{Fe}_{3} \mathrm{C}$ "leaf" was used as the electrode material which was hard to be passivated by oxygen (Schnepp et al., 2010). The leaf extract-templated $\mathrm{Pt}$ or $\mathrm{Ag}$ nanoparticals exhibited excellent biocompatibility (Huang et al., 2011; Zheng et al., 2013).

Considering the significance of these properties to the field of electroanalytical chemistry, it makes sense to explore the leaftemplated metal oxide micro/nano materials as direct electrochemical biosensing interface. On the direct electrochemical biosensing interface, redox reaction would occur under the catalysis of the interface and electron directly transfers from analytes to the electrode without mediators, so that the electrochemical response would be fast and sensitive. Here, we select cobalt oxide $\left(\mathrm{CO}_{3} \mathrm{O}_{4}\right)$, an important transition metal oxide, as model for the application of leaf-templated materials into electrocatalysis and biosensing due to their excellent catalytic (Xie et al., 2009), electronic (Dong et al., 2012) and electrochemical properties (Ding et al., 2010; Lang et al., 2013). The synthesis is simple, cheap, and environmentally friendly. The as-prepared $\mathrm{Co}_{3} \mathrm{O}_{4}$ inherited the 3D hierarchical porous and interconnected structure from leaves. Further, it was applied to the direct electrochemical non-enzymatic sensor for hydrogen peroxide $\left(\mathrm{H}_{2} \mathrm{O}_{2}\right)$ and glucose, which was cost-effective, rapid, sensitive, selective, reliable and stable. To the best of our knowledge, this is the first report to address the leaf-templated nanomaterials for electrochemical sensing. The concept of this work may be applicable to prepare other metal oxides for a series of applications including sensing, supercapacitor and catalysis, and also represent an important first step towards the design of novel non-enzymatic biofuel cells.

\section{Materials and methods}

\subsection{Chemicals and materials}

Cobalt acetate $\left(\mathrm{Co}(\mathrm{COOH})_{2} \cdot 4 \mathrm{H}_{2} \mathrm{O}\right)$, sodium hydroxide $(\mathrm{NaOH})$ and D-glucose were purchased from Sinopharm Chemical Reagent Corporation (Shanghai, China). Nafion ${ }^{\mathbb{R}}$ perfluorinated resin solution (5 wt\% in mixture of lower aliphatic alcohols and water) were purchased from Sigma-Aldrich. All other reagents are of analytical grade and were used without purification. All aqueous solutions were prepared with Milli-Q water $(18.2 \mathrm{M} \Omega \mathrm{cm})$. The mature gingko leaves were collected from the local park. $\mathrm{H}_{2} \mathrm{O}_{2}$ and glucose solutions with different concentrations were diluted from their respective stock solution with $0.1 \mathrm{M} \mathrm{NaOH}$ solution.

\subsection{Synthesis of $3 \mathrm{D}$ porous $\mathrm{Co}_{3} \mathrm{O}_{4}$}

The mature gingko leaves were treated with $2 \mathrm{M}$ hydrochloric acid solution for $3 \mathrm{~h}$. After rinsing thoroughly with water and subsequent drying at $60^{\circ} \mathrm{C}$ for $3 \mathrm{~h}$, the leaves were subsequently immersed in $0.1 \mathrm{M} \mathrm{Co}\left(\mathrm{CH}_{3} \mathrm{COO}\right)_{2}$ solution at room temperature overnight. After drying at $60{ }^{\circ} \mathrm{C}$, the leaves were calcined in air at $400{ }^{\circ} \mathrm{C}$ for $3 \mathrm{~h}$ and then naturally cooled to room temperature. The remaining powder was washed several times with water and collected by centrifugation. After drying at $60{ }^{\circ} \mathrm{C}$ overnight, the black $\mathrm{CO}_{3} \mathrm{O}_{4}$ was obtained. The powder was finely ground in an agate mortar and stored at room temperature. For the control experiment, non-templated $\mathrm{Co}_{3} \mathrm{O} 4$ was prepared from $\mathrm{Co}\left(\mathrm{CH}_{3} \mathrm{COO}\right)_{2}$ solution by the same method except that the leaf template had not been used.

\subsection{Preparation of the $\mathrm{CO}_{3} \mathrm{O}_{4}$ modified sensor}

Before surface modification, the glassy carbon electrode (GCE, $3 \mathrm{~mm}$ in diameter) was polished with $0.05 \mu \mathrm{m}$ alumina slurry, and sonicated in ethanol and water, respectively. After thorough rinse with water and drying in air, $5 \mu \mathrm{L}$ of $2 \mathrm{mg} / \mathrm{mL}$ as-synthesized porous $\mathrm{CO}_{3} \mathrm{O}_{4}$ aqueous suspension was dropped onto the surface of the inverted electrode and dried in air. Finally, $5 \mu \mathrm{L}$ of Nafion solution ( $0.1 \mathrm{wt} \%$ in ethanol) was dropped onto the electrode in order to entrap $\mathrm{CO}_{3} \mathrm{O}_{4}$. The as-prepared modified electrode was denoted as Nafion $/ \mathrm{Co}_{3} \mathrm{O}_{4} / \mathrm{GCE}$. Before use, the modified electrodes were washed with water to remove any loosely combined modifiers. The Nafion-coated GCE (Nafion/GCE) and the Nafion/nontemplated $\mathrm{Co}_{3} \mathrm{O}_{4} / \mathrm{GCE}$ were also prepared as a control electrodes by the same process.

\subsection{Apparatus and electrochemical measurements}

The morphology of the as-prepared $\mathrm{Co}_{3} \mathrm{O}_{4}$ was observed by the field emission scanning electron microscopy (FE-SEM, HITACHI S-4800) and transmission electron microscopy (TEM, HITACHI $\mathrm{H}-7650$ ). X-ray diffraction (XRD) patterns were recorded on a Bruker-AXS Micro-diffractometer (D8 ADVANCE) at room temperature. Electrochemical measurements were performed on a $\mathrm{CHI}$ $660 \mathrm{E}$ electrochemical workstation $(\mathrm{CH}$ Instruments, Chenhua, Shanghai, China). All electrochemical measurements were carried out at room temperature in a conventional three-electrode system with a modified GCE as the working electrode, a platinum wire as the counter electrode and a saturated calomel electrode (SCE) as the reference electrode. For chronoamperometry, all measurements were performed at appropriate potential on successive injection of analytes in stirring $0.1 \mathrm{M} \mathrm{NaOH}$ solution and the effect of dilution on the final concentration had been taken into consideration.

\section{Results and discussion}

\subsection{Synthesis and structure of $\mathrm{Co}_{3} \mathrm{O}_{4}$ from leaf biotemplates}

Here, we developed a simple, environmentally friendly and cost-effective method for the synthesis of 3D hierarchical porous $\mathrm{Co}_{3} \mathrm{O}_{4}$ with leaf template. The gingko leaf was selected as template, because gingko trees are widely planted in our country and their leaves are available easily. Meanwhile, this kind of leaf has relatively uniform texture without thick vein, which is favorable 
for obtaining the relatively uniform porous product. Admittedly, other kinds of leaves may trigger the similar effect with the previous reports (Li et al., 2009; Schnepp et al., 2010; Yang et al., 2013 ) in getting 3D hierarchical porous nanostructures, due to the similarities of components and structures of various leaves. In addition, gingko leaf is a kind of important medicinal plant and this study may further expand its economic value. The mature leaves were pretreated with $\mathrm{HCl}$ to remove any impure elements, such as $\mathrm{K}, \mathrm{Ca}, \mathrm{Fe}, \mathrm{P}$ and $\mathrm{S}$. In addition, the leaves turned red after $3 \mathrm{~h}$, implying that $\mathrm{Mg}^{2+}$ ions in the porphyrins of the chlorophylls were replaced by $\mathrm{H}^{+}$during this treatment, which could be helpful for other metal ions to substitute the magnesium ions $\left(\mathrm{Mg}^{2+}\right)$ in the chlorophylls (Li et al., 2009). The acid-treated leaves were immersed in $\mathrm{Co}\left(\mathrm{CH}_{3} \mathrm{COO}\right)_{2}$ solution to adsorb cobalt ions $\left(\mathrm{Co}^{2+}\right)$ and became yellowish-brown after about two hours and the color gradually deepened to dark brown overnight. Subsequently, the brown leaves were heated at $400{ }^{\circ} \mathrm{C}$ in air for the calcination and removal of the original substances. The black calcined products retained the shape of the original leaves, but were loose in texture. The whole preparation process is graphically demonstrated in Scheme S1 (Supplementary data).

To study the morphology and the formation mechanism of the product, SEM and TEM were applied for the characterization of the raw leaves and calcined products. On the epidermis layer of gingko leaf, epidermis cells, guard cells, veins and stomas could be clearly observed (Fig. 1A), where the epidermis cells were irregularly distributed with the slender cells at veins closely aligning to form a long "string" and the dispersive stomas were surrounded by several guard cells. Due to these unique structures, gingko leaftemplated products were prepared. As shown in Fig. 1B, the winkled surface of the products was very similar to the surface of original epidermis layer, indicating that the as-prepared products had been successfully replicated by our method. Furthermore, the hierarchal structure could be clearly observed from the high-magnification SEM image (Fig. 1C). Meanwhile, the wrinkled surface was also composed of some uniformly interconnected $\mathrm{Co}_{3} \mathrm{O}_{4}$ nanoparticles of 30-100 nm (Fig. 1D). Due to the agglomeration of $\mathrm{CO}_{3} \mathrm{O}_{4}$ nanoparticles with each other, the porous framework has a disordered worm-hole-like porous structure in a wide range $(10-200 \mathrm{~nm})$. The leaf-templated $\mathrm{CO}_{3} \mathrm{O}_{4}$ had a 3D hierarchical structure from TEM image (Fig. 2A), which agrees well with SEM image (Fig. 1C). In the further TEM magnification, the $\mathrm{Co}_{3} \mathrm{O}_{4}$ nanoparticles with irregular shapes were interconnected with each other to form a multilayer network structure (Fig. 2B), which shows hierarchical structural characters.

The crystal structure and the phase purity of the as-prepared $\mathrm{CO}_{3} \mathrm{O}_{4}$ were characterized by XRD (Fig. 3 ). The XRD spectrum of asprepared $\mathrm{Co}_{3} \mathrm{O}_{4}$ coincided with the diffraction peaks at $2 \theta$ values of $19.00^{\circ}, 31.27^{\circ}, 36.85^{\circ}, 38.54^{\circ}, 44.81^{\circ}, 56.66^{\circ}, 59.36^{\circ}, 65.24^{\circ}, 74.12^{\circ}$, which corresponded to (111), (220), (331), (222), (440), (422), (511), (440), (531) and (620) crystal planes, respectively in the standard spectrum of centered cubic crystalline $\mathrm{Co}_{3} \mathrm{O}_{4}$ (JCPDS 421467), indicating the formation of cubic crystalline $\mathrm{CO}_{3} \mathrm{O}_{4}$. No other impurities could be detected in the XRD pattern of $\mathrm{CO}_{3} \mathrm{O}_{4}$, suggesting that the pure $\mathrm{CO}_{3} \mathrm{O}_{4}$ was obtained.

Based on the above results, a possible formation mechanism of the 3D hierarchical porous $\mathrm{CO}_{3} \mathrm{O}_{4}$ could be deduced. The original leaf was mainly made up of mesophyll cells, veins and stoma, endowing it with 3D hierarchical porous and interconnected structures. The surface of the cell walls was predominantly
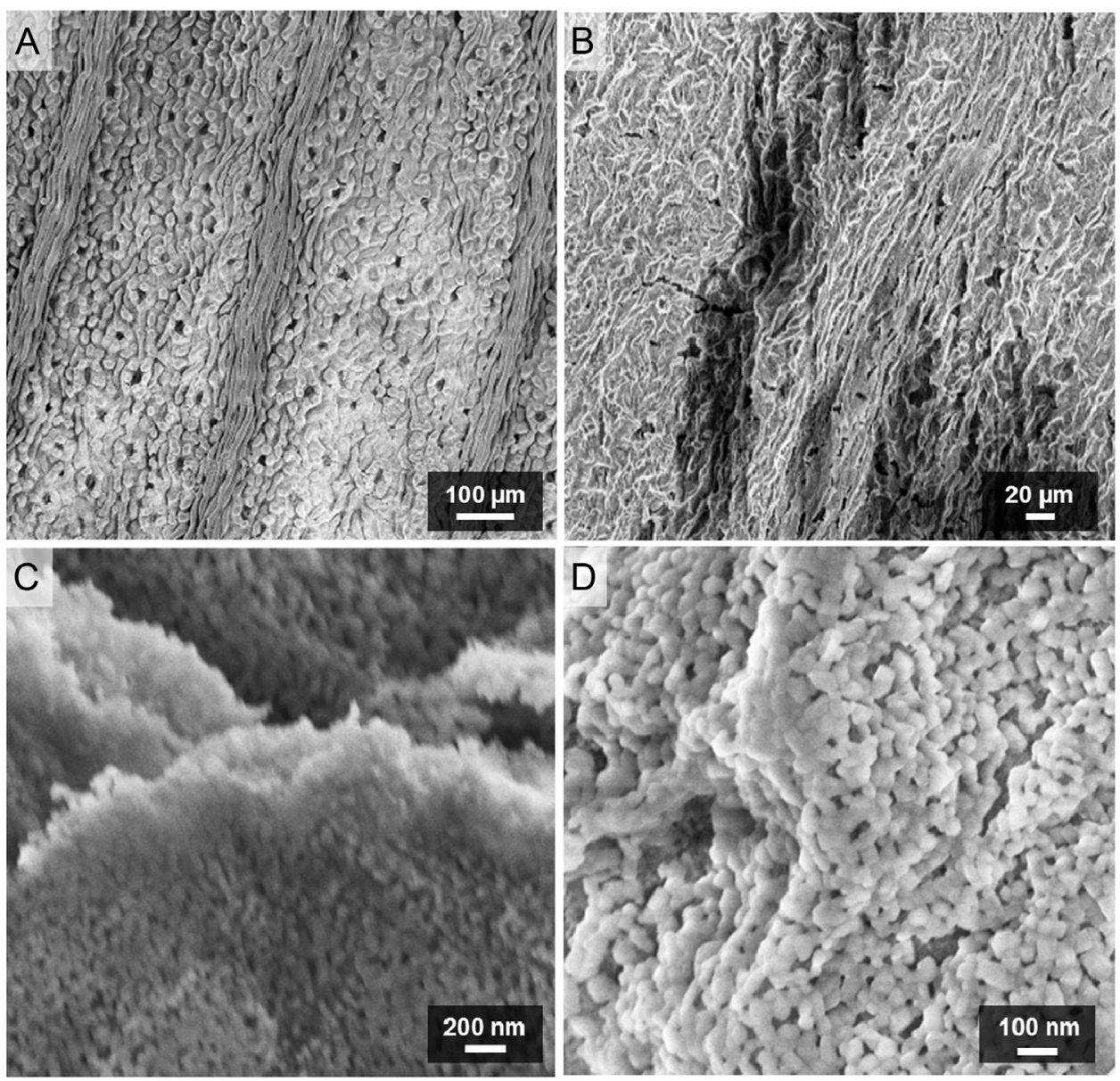

Fig. 1. SEM images of the original gingko leaf (A) and leaf templated-co3o4 with low-magnification (B) and high-magnification (C and D). 

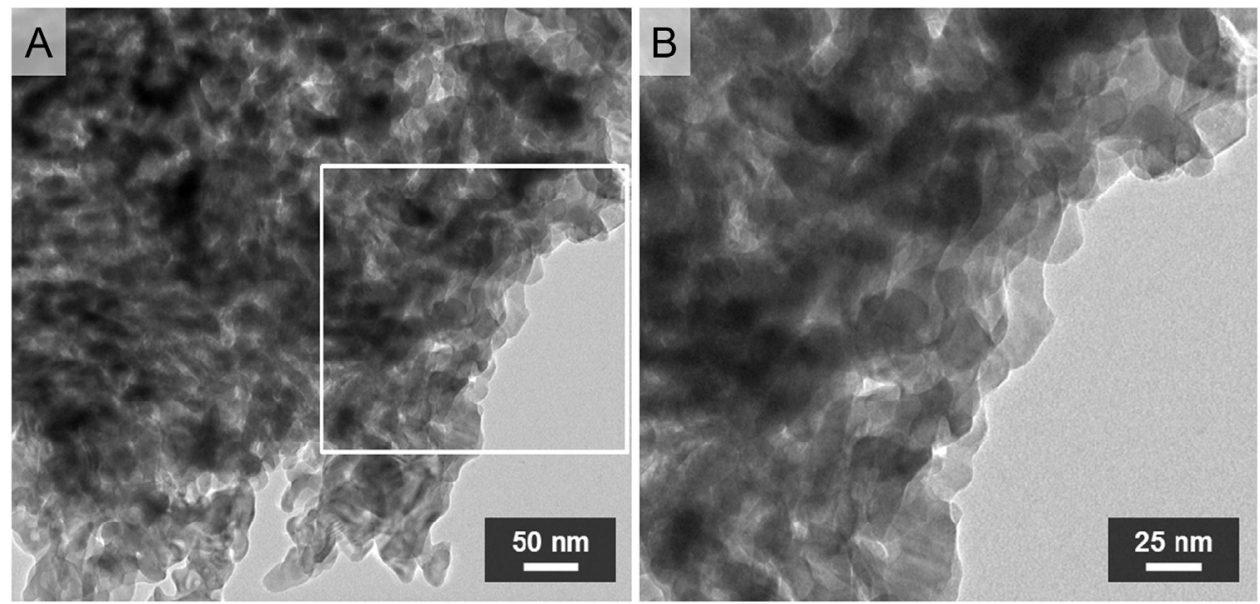

Fig. 2. TEM images of leaf-templated $\mathrm{Co}_{3} \mathrm{O}_{4}(\mathrm{~A})$ and the further magnification of the corresponding square area (B).

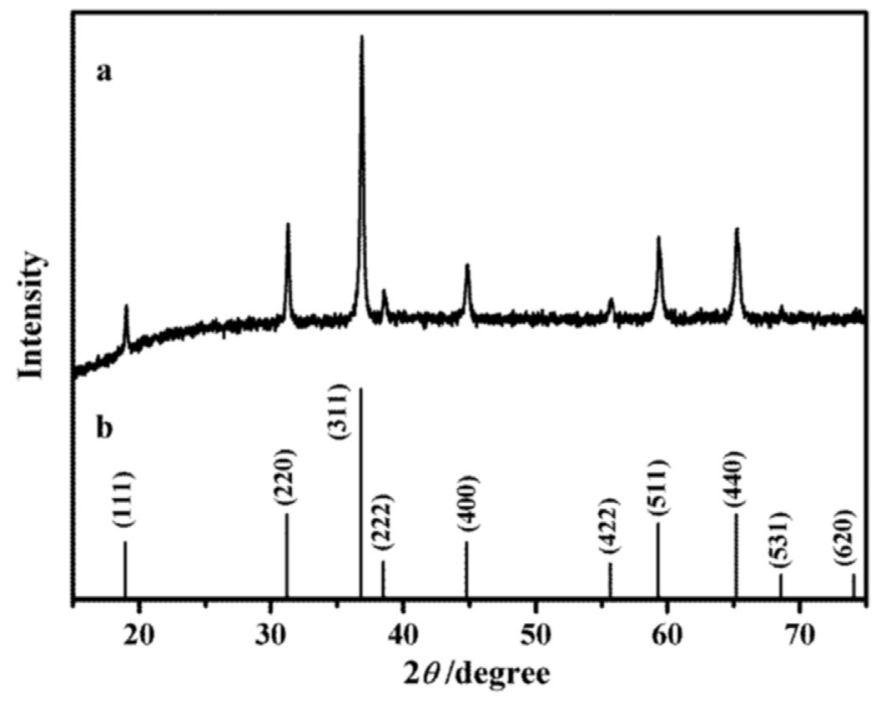

Fig. 3. XRD patterns of the as-prepared $\mathrm{Co}_{3} \mathrm{O}_{4}$ (a) and the standard values of $\mathrm{Co}_{3} \mathrm{O}_{4}$ (JCPDS 42-1467) (b). The diffraction peaks corresponding to (111), (220), (331), (222), (440), (422), (511), (440), (531) and (620) crystal planes was at $2 \theta$ values of $19.00^{\circ}, 31.27^{\circ}, 36.85^{\circ}, 38.54^{\circ}, 44.81^{\circ}, 56.66^{\circ}, 59.36^{\circ}, 65.24^{\circ}, 74.12^{\circ}$, respectively.

covered with celluloses, lignins and proteins, which carried a great deal of carboxyl, and hydroxyl functional groups. The membranes of cells and organelles were made up of phospholipids and proteins, carrying a great deal of phosphomonoester, phosphodiester, carboxyl and hydroxyl functional groups (Gibson, 2012). In addition, porphyrins of the chlorophylls could presumably chelate with transition metal ions (Li et al., 2009). These functional groups could interact with the $\mathrm{Co}^{2+}$ to form the supramolecular organicinorganic composite through strong interactions. After heating at high temperature $\left(400{ }^{\circ} \mathrm{C}\right)$ in the air, the leaves disappeared in the form of $\mathrm{CO}_{2}, \mathrm{H}_{2} \mathrm{O}$ and other gases, leaving a 3D hierarchical porous and interconnected inorganic framework structure. The mechanism of calcination could be presumably proposed as Eq. (1):

$3 \mathrm{Co}\left(\mathrm{CH}_{3} \mathrm{COOH}\right)_{2}+8 \mathrm{O}_{2} \rightarrow \mathrm{Co}_{3} \mathrm{O}_{4}+12 \mathrm{CO}_{2}$

In the context, other methods have been successfully applied to synthesize $\mathrm{Co}_{3} \mathrm{O}_{4}$ nanostructures, such as porous $\mathrm{Co}_{3} \mathrm{O}_{4}$ microspheres by solvothermal method (Sun et al., 2011), graphene/ $\mathrm{CO}_{3} \mathrm{O}_{4}$ nanowires by autoclaving (Dong et al., 2012), gold supported cobalt oxide wires by cetyltrimethylammonium bromideassisted autoclaving (Lang et al., 2013), $\mathrm{CO}_{3} \mathrm{O}_{4}$ nanoplates by ethylene glycol-assisted autoclaving (Yu et al., 2013), and $\mathrm{Co}_{3} \mathrm{O}_{4}$ nanofibers by poly(vinyl pyrrolidone)-assisted electrospinning (Ding et al., 2010). Obviously, the leaf-templated $\mathrm{Co}_{3} \mathrm{O}_{4}$ synthesis offers many advantages including resourceful biomass materials, simple synthesis technique and equipment as well as elimination of the use of any environmentally hazardous surfactants or organic solvents. Moreover, the formation of 3D hierarchical porous structures is possible by our approach.

\subsection{Electrochemical characterization of the Nafion/ $/ \mathrm{Co}_{3} \mathrm{O}_{4} / G C E$}

To study the electrochemical behavior of the leaf-templated $\mathrm{Co}_{3} \mathrm{O}_{4}$ nanomaterials, cyclic voltammograms (CVs) of the asprepared Nafion $/ \mathrm{CO}_{3} \mathrm{O}_{4} / \mathrm{GCE}$ was first investigated in low-strength alkaline solution $(0.1 \mathrm{M} \mathrm{NaOH})$. As shown in Fig. 4, two pairs of well-defined redox peaks were observed at Nafion $/ \mathrm{CO}_{3} \mathrm{O}_{4} / \mathrm{GCE}$ (Fig. 4, curve b), while no obvious response was found at the Nafion/GCE (Fig. 4, curve a), indicating the excellent electrocatalytic performance of the porous $\mathrm{Co}_{3} \mathrm{O}_{4}$. Meanwhile, no obvious peak was obtained in the neutral solution (PBS buffer, $\mathrm{pH} 7.4$ ) at Nafion/ $\mathrm{CO}_{3} \mathrm{O}_{4} / \mathrm{GCE}$ (Fig. 4, curve c), suggesting the necessity of $\mathrm{OH}^{-}$in the electrochemical redox reaction of $\mathrm{Co}_{3} \mathrm{O}_{4}$ and was consistent with the previous report (Ding et al., 2010). In addition, the non-templated $\mathrm{Co}_{3} \mathrm{O}_{4}$ had also not obvious response (Fig. 4, curve $\mathrm{d}$ in Fig. S1, Supplementary data), indicating the porous nanostructure could affect the sensors performance. As labeled in Fig. 4, two pairs of

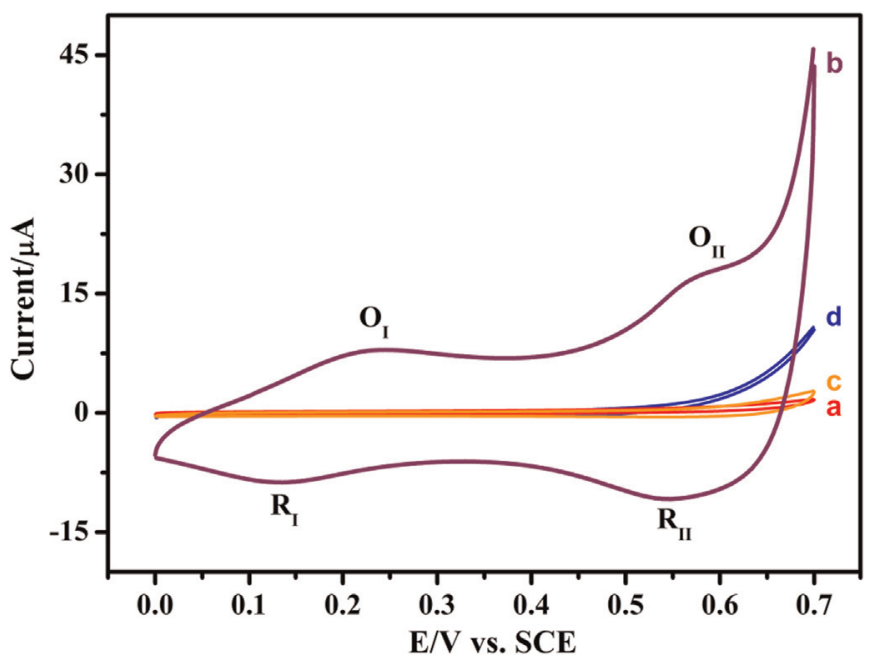

Fig. 4. $\mathrm{CVs}$ of Nafion/GCE in $0.1 \mathrm{M} \mathrm{NaOH}$ solution (a), Nafion/ $\mathrm{Co}_{3} \mathrm{O}_{4} / \mathrm{GCE}$ in $0.1 \mathrm{M}$ $\mathrm{NaOH}$ solution (b) and PBS buffer ( $\mathrm{pH} 7.4)(\mathrm{c})$, and Nafion/non-templated $\mathrm{Co}_{3} \mathrm{O}_{4}$ /GCE in $0.1 \mathrm{M} \mathrm{NaOH}$ solution (d). Scan rate, $25 \mathrm{mV} / \mathrm{s}$. 
redox peaks $\left(\mathrm{O}_{\mathrm{I}} / \mathrm{R}_{\mathrm{I}}\right.$ and $\left.\mathrm{O}_{\mathrm{II}} / \mathrm{R}_{\mathrm{II}}\right)$ can presumably result from the reversible transformation between $\mathrm{Co}_{3} \mathrm{O}_{4}$ and $\mathrm{CoOOH}\left(\mathrm{O}_{\mathrm{I}} / \mathrm{R}_{\mathrm{I}}\right)$ and the further conversion between $\mathrm{CoOOH}$ and $\mathrm{CoO}_{2}\left(\mathrm{O}_{\mathrm{II}} / \mathrm{R}_{\mathrm{II}}\right)$, respectively (Casella and Gatta, 2002). These two reversible reactions can be schematically expressed as Eqs. (2) and (3):

$\mathrm{Co}_{3} \mathrm{O}_{4}+\mathrm{OH}^{-}+\mathrm{H}_{2} \mathrm{O} \underset{\mathrm{R}_{\mathrm{I}}}{\stackrel{\mathrm{O}_{\mathrm{I}}}{\rightleftharpoons}} 3 \mathrm{CoOOH}+e^{-}$

$\mathrm{CoOOH}+\mathrm{OH}^{-} \underset{\mathrm{R}_{\mathrm{II}}}{\stackrel{\mathrm{O}_{\mathrm{II}}}{\rightleftarrows}} \mathrm{COO}_{2}+\mathrm{H}_{2} \mathrm{O}+e^{-}$

In addition, we researched the effect of scan rates on CV responses (Fig. S2, Supplementary data). Both the redox peak currents were increased with the increase of scan rate, while the peak potentials remained almost unchanged. Both the redox peak currents increased linearly with the scan rate within the range from 10 to $200 \mathrm{mV} / \mathrm{s}$, indicating a surface-controlled electrochemical process.

\subsection{Electrooxidation of $\mathrm{H}_{2} \mathrm{O}_{2}$ at the Nafion/ $\mathrm{CO}_{3} \mathrm{O}_{4} / \mathrm{GCE}$}

CVs of the Nafion/ $/ \mathrm{Co}_{3} \mathrm{O}_{4} / \mathrm{GCE}$ sensor in $0.1 \mathrm{M} \mathrm{NaOH}$ solutions containing the various concentration of $\mathrm{H}_{2} \mathrm{O}_{2}$ were performed. At Nafion $/ \mathrm{Co}_{3} \mathrm{O}_{4} / \mathrm{GCE}$, the oxidation peak current $\left(i_{\text {pa }}\right)$ around $0.31 \mathrm{~V}$ (presumably corresponding to $\mathrm{Co}_{3} \mathrm{O}_{4} / \mathrm{CoOOH}$ pair) increased with the increase of $\mathrm{H}_{2} \mathrm{O}_{2}$ concentration in solution (Fig. $5 \mathrm{~A}$, curves $\mathrm{b}-\mathrm{e}$ ), indicating that the as-prepared nanoporous $\mathrm{CO}_{3} \mathrm{O}_{4}$ had high catalytic ability for $\mathrm{H}_{2} \mathrm{O}_{2}$ oxidation. No redox peak was observed at Nafion/GCE even in $3 \mathrm{mM} \mathrm{H}_{2} \mathrm{O}_{2}$ (Fig. 5A, curve a). The mechanism of the $\mathrm{H}_{2} \mathrm{O}_{2}$ electrochemical oxidation reaction could be presumably expressed as the following Eq. (4) (Salimi et al., 2007):

$6 \mathrm{CoOOH}+\mathrm{H}_{2} \mathrm{O}_{2} \rightarrow 2 \mathrm{Co}_{3} \mathrm{O}_{4}+\mathrm{O}_{2}+4 \mathrm{H}_{2} \mathrm{O}$

With the consumption of $\mathrm{CoOOH}$ and the production of $\mathrm{Co}_{3} \mathrm{O}_{4}$, the forward reaction $\left(\mathrm{CO}_{3} \mathrm{O}_{4} \rightarrow \mathrm{CoOOH}\right)$ for Eq. (2) would be greatly favored, which resulted in an enhanced oxidation current at peak $\mathrm{O}_{\mathrm{I}}$ upon the addition of $\mathrm{H}_{2} \mathrm{O}_{2}$. Similarly, no obvious peak was observed in the neutral buffer (Fig. 5A, curve f), indicating the critical role of $\mathrm{OH}^{-}$in the $\mathrm{H}_{2} \mathrm{O}_{2}$ oxidation. The experimental phenomena were in good agreement with Eqs. (2)-(4).

\subsection{Non-enzymatic chronoamperometric detection of $\mathrm{H}_{2} \mathrm{O}_{2}$}

In order to evaluate the performance of electrochemical analysis for $\mathrm{H}_{2} \mathrm{O}_{2}$, the non-enzymatic chronoamperometric detection of $\mathrm{H}_{2} \mathrm{O}_{2}$ was performed at $+0.31 \mathrm{~V}$. As shown in Fig. 5B, the typical I$t$ curve on successive injection of $\mathrm{H}_{2} \mathrm{O}_{2}$ reached $95 \%$ of steady-state current in less than $4 \mathrm{~s}$, indicating the as-prepared non-enzymatic sensor exhibited a rapid response to the addition of $\mathrm{H}_{2} \mathrm{O}_{2}$. The linear range is from $0.4 \mu \mathrm{M}$ to $0.2 \mathrm{mM} \mathrm{H}_{2} \mathrm{O}_{2}$ (Fig. $5 \mathrm{C}$ ). The linear regression equation is $y=27.549 x+0.603$ with the correlation coefficient ( $R$ ) of 0.998 . The limit of detection (LOD) was estimated to be about $0.24 \mu \mathrm{M} \mathrm{H}_{2} \mathrm{O}_{2}(\mathrm{~S} / \mathrm{N}=3)$, which was lower than the previous reports, such as $0.68 \mu \mathrm{M}$ for Pd nanoparticle assembly(Han et al., 2012) and $4 \mu \mathrm{M}$ for $\mathrm{SiO}_{2}$-coated graphene oxide-based non-enzymatic sensors (Lu et al., 2011). The LOD $(0.24 \mu \mathrm{M})$ was slightly higher than that $(0.1 \mu \mathrm{M})$ reported for FeS-based $\mathrm{H}_{2} \mathrm{O}_{2}$ sensor. However, the dynamic linear range of our case was wider than that $(0.5-150 \mu \mathrm{M})$ of $\mathrm{FeS}$-based $\mathrm{H}_{2} \mathrm{O}_{2}$ sensor (Dai et al., 2009). The sensitivity was calculated to be $389.7 \mu \mathrm{A} \mathrm{mM}^{-1} \mathrm{~cm}^{-2}$, which was higher than $101.3 \mu \mathrm{A} \mathrm{mM}{ }^{-1} \mathrm{~cm}^{-2}$ for nanoporous Ag@BSA/ Au-based $\mathrm{H}_{2} \mathrm{O}_{2}$ sensor (Liu et al., 2013a, 2013b). These results indicated that the proposed non-enzymatic sensor for $\mathrm{H}_{2} \mathrm{O}_{2}$ detection had a faster response, a higher sensitivity, and a lower LOD than the values reported previously.
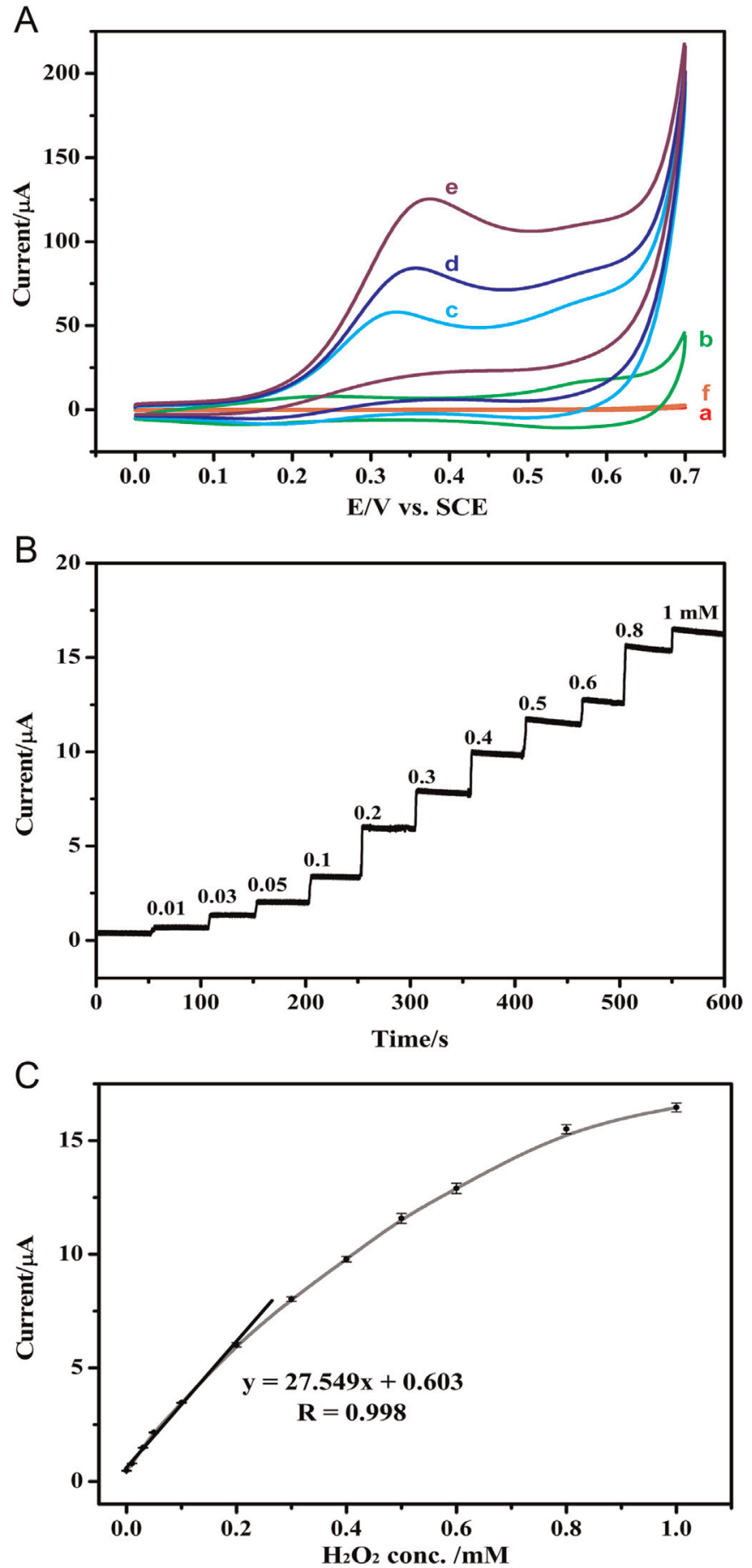

Fig. 5. (A) CVs of Nafion/GCE in $0.1 \mathrm{M} \mathrm{NaOH}$ solution containing $3 \mathrm{mM} \mathrm{H}_{2} \mathrm{O}_{2}$ (a), Nafion/ $/ \mathrm{Co}_{3} \mathrm{O}_{4} / \mathrm{GCE}$ in $0.1 \mathrm{M} \mathrm{NaOH}$ solutions containing 0 (b), 1 (c), 2 (d) and $3 \mathrm{mM}$ $\mathrm{H}_{2} \mathrm{O}_{2}$ (e), and Nafion/ $\mathrm{Co}_{3} \mathrm{O}_{4} / \mathrm{GCE}$ sensor in PBS buffer ( $\mathrm{pH} 7.4$ ) containing $3 \mathrm{mM}$ $\mathrm{H}_{2} \mathrm{O}_{2}$ (f). Scan rate, $25 \mathrm{mV} / \mathrm{s}$. (B) Typical i-t curve obtained at Nafion $/ \mathrm{Co}_{3} \mathrm{O}_{4} / \mathrm{GCE}$ sensor on the successive injection of $\mathrm{H}_{2} \mathrm{O}_{2}$ in $0.1 \mathrm{M} \mathrm{NaOH}$ solution, on which the concentration denoted the $\mathrm{H}_{2} \mathrm{O}_{2}$ concentration (final concentration). Applied potential: $+0.31 \mathrm{~V}$ (vs. SCE). (C) The typical calibration graph of the detection for $\mathrm{H}_{2} \mathrm{O}_{2}$.

\subsection{Electrooxidation of glucose at the Nafion/ $/ \mathrm{CO}_{3} \mathrm{O}_{4} / \mathrm{GCE}$}

To confirm the electrooxidation behavior of glucose at the Nafion $/ \mathrm{Co}_{3} \mathrm{O}_{4} / \mathrm{GCE}$, the CVs were measured with varying glucose concentrations in $0.1 \mathrm{M} \mathrm{NaOH}$ solutions. An obvious increase in $i_{\mathrm{pa}}$ at peak $\mathrm{O}_{\text {II }}$ was observed in $0.1 \mathrm{M} \mathrm{NaOH}$ solution (curve b) upon the addition of $0.1 \mathrm{mM}$ glucose (Fig. 6A, curve c). Further, the $i_{\mathrm{pa}}$ 
A

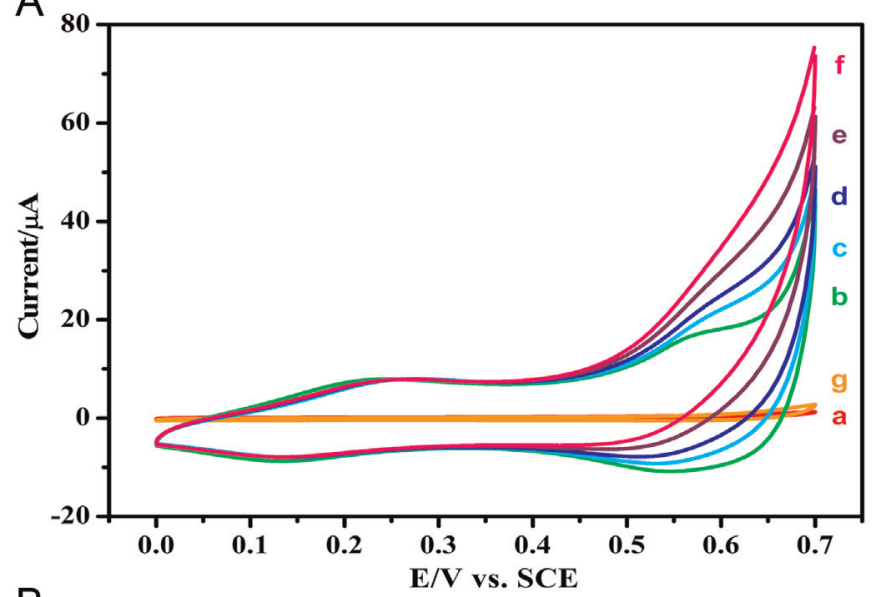

$\mathrm{B}$

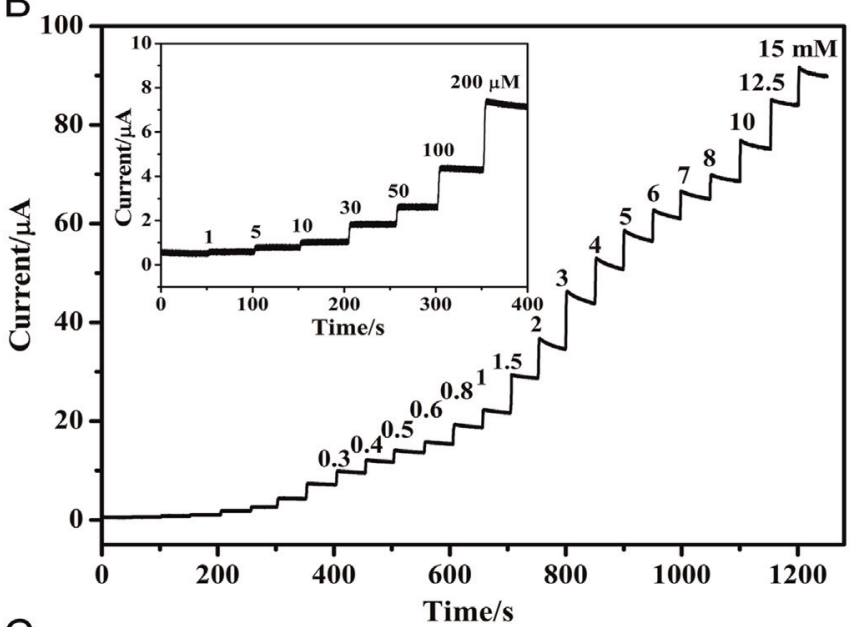

C

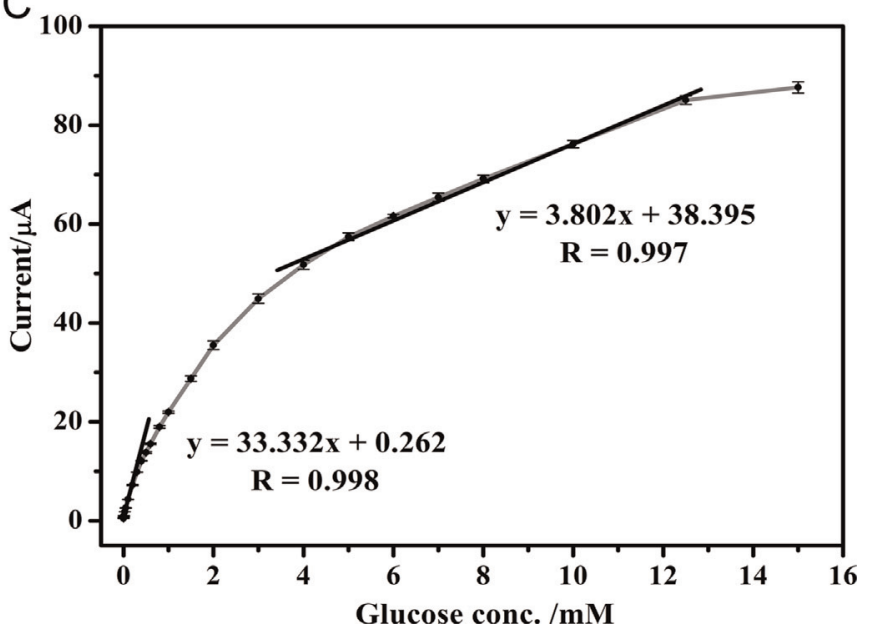

Fig. 6. (A) CVs of Nafion/GCE in $0.1 \mathrm{M} \mathrm{NaOH}$ solution containing $1 \mathrm{mM}$ glucose (a), Nafion/ $\mathrm{CO}_{3} \mathrm{O}_{4} / \mathrm{GCE}$ in $0.1 \mathrm{M} \mathrm{NaOH}$ solutions containing 0 (b), 0.1 (c), 0.2 (d), 0.5 (e) and $1 \mathrm{mM}$ glucose (f), and Nafion/ $\mathrm{Co}_{3} \mathrm{O}_{4} / \mathrm{GCE}$ in PBS buffer ( $\mathrm{pH} 7.4$ ) containing $1 \mathrm{mM}$ glucose $(\mathrm{g})$. Scan rate, $25 \mathrm{mV} / \mathrm{s}$. (B) Typical $i-t$ curve obtained at Nafion $/ \mathrm{Co}_{3} \mathrm{O}_{4}$ /GCE sensor on the successive injection of glucose in $0.1 \mathrm{M} \mathrm{NaOH}$ solution, on which the concentration denoted the glucose concentration (final concentration). Inset: the magnified curve for $1-300 \mu \mathrm{M}$ glucose. Applied potential: $+0.59 \mathrm{~V}$. (C) The typical calibration graph for glucose.

values increased with the increase of glucose concentration from $0.1 \mathrm{mM}$ to $1 \mathrm{mM}$ (Fig. 6A, curves $\mathrm{c}-\mathrm{f}$ ). However, there was no obvious current change at the Nafion/GCE in $1 \mathrm{mM}$ glucose (Fig. 6A, curve a). These results indicated the excellent electrocatalytic activity of the $\mathrm{Co}_{3} \mathrm{O}_{4}$ for glucose oxidation. In terms of the further observation, the current increase (Fig. 6A, curves b-f) with the addition of glucose at peak $\mathrm{O}_{\mathrm{II}}\left(\mathrm{CoOOH} \rightarrow \mathrm{CoO}_{2}\right)$ was much stronger than that at peak $\mathrm{O}_{\mathrm{I}}\left(\mathrm{CO}_{3} \mathrm{O}_{4} \rightarrow \mathrm{CoOOH}\right)$, which may be reasonable to assume that the electrooxidation of glucose was mainly mediated by $\mathrm{CoOOH} / \mathrm{CoO}_{2}$ rather than $\mathrm{Co}_{3} \mathrm{O}_{4} / \mathrm{CoOOH}$ in an alkaline solution. The result indicated that the catalytic activity of the as-prepared $\mathrm{Co}_{3} \mathrm{O}_{4}$ towards glucose oxidation in alkaline solution was related to $\mathrm{CoOOH}$ and $\mathrm{CoO}_{2}$. Therefore, the peak $\mathrm{O}_{\mathrm{II}}$ potential $(+0.59 \mathrm{~V})$ was applied for subsequent chronoamperometric detection of glucose. It is widely accepted that glucose can be oxidized to gluconolactone through a two-electron electrochemical reaction (Park et al., 2006). The mechanism of electrochemical oxidation of glucose catalyzed by $\mathrm{Co}_{3} \mathrm{O}_{4}$ could be presumably proposed as the following Eq. (5):

$$
\begin{aligned}
& 2 \mathrm{CoO}_{2}+\mathrm{C}_{6} \mathrm{H}_{12} \mathrm{O}_{6} \text { (glucose) } \\
& \quad \rightarrow 2 \mathrm{CoOOH}+\mathrm{C}_{6} \mathrm{H}_{10} \mathrm{O}_{6} \text { (gluconolactone) }
\end{aligned}
$$

With the consumption of $\mathrm{CoO}_{2}$ and the production of $\mathrm{CoOOH}$, the forward reaction $\left(\mathrm{CoOOH} \rightarrow \mathrm{CoO}_{2}\right)$ for Eq. (3) would be greatly favored, resulting in an enhanced $i_{\mathrm{pa}}$ for peak $\mathrm{O}_{\mathrm{II}}$ upon the addition of glucose. Interestingly, no response to glucose $(1 \mathrm{mM})$ was observed for the as-prepared sensor in neutral PBS solution (Fig. 6, curve g), indicating the critical role of $\mathrm{OH}^{-}$in the glucose oxidation. The experimental phenomena were consistent with Eqs. (2), (3) and (5).

\subsection{Non-enzymatic chronoamperometric detection of glucose}

Considering that the $i_{\text {pa }}$ at peak $\mathrm{O}_{\mathrm{II}}(+0.59 \mathrm{~V})$ increased significantly with the increase of glucose concentration from CV measurements (Fig. 6A), an potential of $+0.59 \mathrm{~V}$ was applied to the non-enzymatic chronoamperometric detection of glucose at Nafion/ $/ \mathrm{CO}_{3} \mathrm{O}_{4} / \mathrm{GCE}$ in the stirring $0.1 \mathrm{M} \mathrm{NaOH}$ solution (Fig. 6B). The typical $i-t$ curve on successive injection of glucose reached $95 \%$ of steady-state current in less than $3 \mathrm{~s}$, indicating the asprepared non-enzymatic sensor exhibited a rapid response to glucose. The calibration curve was plotted (Fig. 6C). There were two linear ranges, one of which was $1-300 \mu \mathrm{M}$ with the linear regression equation of $y=33.332 x+0.262(R=0.998)$. The LOD was estimated to be about $0.1 \mu \mathrm{M}$ glucose $(\mathrm{S} / \mathrm{N}=3)$, which is the lowest among the reported non-enzymatic glucose sensors (Liu et al., 2008; Meng et al., 2009; Ding et al., 2010; Ryu et al., 2010; Han et al., 2014). The sensitivity for the sensor was calculated to be $471.5 \mu \mathrm{A} \mathrm{mM}^{-1} \mathrm{~cm}^{-2}$, which was much higher than $1.06 \mu \mathrm{A} \mathrm{mM}^{-1} \mathrm{~cm}^{-2}$ for single-walled carbon nanohorn- (Liu, 2008), $9.6 \mu \mathrm{A} \mathrm{mM}^{-1} \mathrm{~cm}^{-2}$ for mesoporous Pt- (Park et al., 2003), $10.65 \mu \mathrm{A} \mathrm{mM}^{-1} \mathrm{~cm}^{-2}$ for gold-cluster film- (Han et al., 2014), $10.71 \mu \mathrm{A} \mathrm{mM}^{-1} \mathrm{~cm}^{-2}$ for platinum@gold alloy- (Ryu et al., 2010), $36.25 \mu \mathrm{A} \mathrm{mM}^{-1} \mathrm{~cm}^{-2}$ for $\mathrm{Co}_{3} \mathrm{O}_{4}$ nanofiber- (Ding et al., 2010) and $160 \mu \mathrm{A} \mathrm{mM}^{-1} \mathrm{~cm}^{-2}$ for Pd nanoparticle/single-walled carbon nanotube-based glucose electrochemical sensors (Meng et al., 2009), respectively. These data indicated that the as-prepared non-enzymatic sensor exhibited a sensitive response to glucose. The high sensitivity and low detection limit could be attributed to the excellent catalytic property of the leaf-templated $\mathrm{Co}_{3} \mathrm{O}_{4}$ and the highly porous $3 \mathrm{D}$ network of $\mathrm{Co}_{3} \mathrm{O}_{4}$, which provided high specific surface area and numerous active sites, and also allowed the access of analytes to the active catalytic sites with minimal diffusion resistance. In addition, the calibration curve had another linear range from $4 \mathrm{mM}$ to $12.5 \mathrm{mM}$. The linear regression equation was $\mathrm{y}=3.802 \mathrm{x}+38.395$ with $R$ of 0.997 . However, the curve reached saturation at a higher glucose concentration. Moreover, the small drift of baseline was observed after continuous injections of glucose, probably due to the faster consumption of glucose in comparison with its diffusion, the slight variation of local $\mathrm{pH}$, or 
the blocking effect of intermediates on the electrocatalytic active sites (Ding et al., 2010).

\subsection{Selectivity and stability of the sensor and detection of glucose in real samples}

The selectivity of the Nafion $/ \mathrm{Co}_{3} \mathrm{O}_{4} / \mathrm{GCE}$ sensor was also investigated against general co-existence of interfering species with glucose such as ascorbic acid (AA), uric acid (UA), dopamine (DA) and acetaminophen (AP). Because the blood glucose level of a normal human body is between $4 \mathrm{mM}$ and $7 \mathrm{mM}$ (Park et al., 2006) and the normal physiological levels of AA, UA and AP in human blood are $0.125 \mathrm{mM}, 0.33 \mathrm{mM}$ and $0.13 \mathrm{mM}$, respectively (Yang et al., 1998; Hrapovic and Luong, 2003), the molar ratio of 5:1 (glucose to each interferent) was used. The i-t curve of the sensor was detected on the successive injection $(0.2 \mathrm{mM})$ of glucose at different stages and the injection $(20 \mu \mathrm{M})$ of $\mathrm{AA}, \mathrm{UA}$, $\mathrm{AP}$ and DA into the stirring $0.1 \mathrm{M} \mathrm{NaOH}$ solution at an applied potential of $+0.59 \mathrm{~V}$. Glucose was added to the solution before and after each addition of the four interferents. There is less than $4 \%$ current increase in the presence of $A A$ and UA, suggesting the proposed sensor had a fair resistant to AA and UA (Fig. S3, Supplementary data), which might be attributed to the repelling effect of both the negatively charged Nafion and negatively charged $\mathrm{Co}_{3} \mathrm{O}_{4}$ (Vickers et al., 2009) against negatively charged $\mathrm{AA}$ and $\mathrm{UA}$ in $0.1 \mathrm{M} \mathrm{NaOH}$ solution (Scheme S2, Supplementary data). AP and DA had no effect to the measurement of glucose (Fig. S3, Supplementary data), and the results were similar with other phenolic compounds (data not shown). The exact reason is unclear for the moment, which might be attributed to the incapability of oxidation of them by $\mathrm{Co}_{3} \mathrm{O}_{4}$.

Since chloride ions $\left(\mathrm{Cl}^{-}\right)$are abundant in nature and can poison some non-enzymatic glucose sensors based on inorganic materials (Park et al., 2006), the influence of $0.15 \mathrm{M} \mathrm{NaCl}$ on the chronoamperometric detection of glucose was also investigated (Fig. S4, Supplementary data). The result indicated that there was nearly no difference between the i-t curves for $50 \mu \mathrm{M}$ glucose in the presence and absence of $0.15 \mathrm{M} \mathrm{NaCl}$, indicating that the sensor can work reliably for the serum sample containing plenty of chloride ions.

The operational stability of the sensor was investigated by the chronoamperometric method. There was about 3\% drift in $i-t$ curve during $30 \mathrm{~min}$ measurement (data not shown). In addition, no measurable decrease in the analytical performance of sensor was found after 60 day storage at room temperature (Fig. S5, Supplementary data), suggesting the good storage stability of the sensor.

In order to confirm the reliability of the as-prepared sensor for analysis of real samples, it was applied on chronoamperometric detection of glucose in human serum samples. The samples were accurately diluted with $0.1 \mathrm{M} \mathrm{NaOH}$ solution to fit into the linear range of the sensor prior to measurements. For each sample, three separate detections were conducted and the blood glucose levels were calculated (Table S1, Supplementary data) based on the linear regression equation obtained from the calibration graph by multiplying the dilution ratios. The relative standard deviation (RSD) values were within 5\%, indicating that the proposed method exhibited high precision and good reproducibility for the detection of blood glucose. The recoveries of the added glucose standards (1 $\mathrm{mM}$ ) were within $97.4-102.1 \%$, demonstrating excellent accuracy of the as-prepared sensor.

\section{Conclusions}

In summary, a novel 3D hierarchical porous $\mathrm{Co}_{3} \mathrm{O}_{4}$ nanomaterial with average particle diameter of $30-100 \mathrm{~nm}$ was synthesized through a simple, cost-effective and environmentally friendly strategy. Further, a non-enzymatic sensor for glucose or $\mathrm{H}_{2} \mathrm{O}_{2}$ was developed based on the $3 \mathrm{D}$ hierarchical porous $\mathrm{Co}_{3} \mathrm{O}_{4}$. The asprepared sensor was simple in preparation, rapid in response, and high sensitive toward glucose and $\mathrm{H}_{2} \mathrm{O}_{2}$. Meanwhile, it also exhibited good anti-interference performance and application potential for detection of blood glucose. The concept of this work may be applicable to prepare a wide range of metal oxide nanostructures. Considering the different size effects and electrocatalytic activities of different synthesis condition and metal oxides, various potential applications including electrochemical sensing interface, supercapacitor, solar cell, fuel cell and catalysis are envisioned.

\section{Acknowledgments}

This work was financially supported by National Natural Science Foundation of China (Nos. 91227116 and 21275152) and the Hundred-Talent-Project (No. KSCX2-YW-BR-7), Chinese Academy of Sciences.

\section{Appendix A. Supplementary Information}

Supplementary data associated with this article can be found in the online version at http://dx.doi.org/10.1016/j.bios.2014.07.031.

\section{References}

Berry, V., Gole, A., Kundu, S., Murphy, C.J., Saraf, R.F., 2005. J. Am. Chem. Soc. 127, $17600-17601$.

Berti, L., Burley, G.A., 2008. Nat. Nanotechnol. 3, 81-87.

Casella, I.G., Gatta, M., 2002. J. Electroanal. Chem. 534, 31-38.

Cen, C., Thiel, S., Mannhart, J., Levy, J., 2009. Science 323, 1026-1030.

Chen, C.L., Rosi, N.L., 2010. Angew. Chem. Int. Ed. 49, 1924-1942.

Dai, Z., Liu, S., Bao, J., Ju, H., 2009. Chemistry - Eur. J. 15, 4321-4326.

Debecker, D.P., Mutin, P.H., 2012. Chem. Soc. Rev. 41, 3624-3650.

Dickerson, M.B., Sandhage, K.H., Naik, R.R., 2008. Chem. Rev. 108, 4935-4978.

Ding, Y., Wang, Y., Su, L., Bellagamba, M., Zhang, H., Lei, Y., 2010. Biosens. Bioelectron. 26, 542-548.

Dong, X.C., Xu, H., Wang, X.W., Huang, Y.X., Chan-Park, M.B., Zhang, H., Wang, L.H., Huang, W., Chen, P., 2012. ACS Nano 6, 3206-3213.

Dujardin, E., Peet, C., Stubbs, G., Culver, J.N., Mann, S., 2003. Nano Lett. 3, 413-417. Ferain, I., Colinge, C.A., Colinge, J.P., 2011. Nature 479, 310-316.

Gibson, L.J., 2012. J. R. Soc. Interface 9, 2749-2766.

Han, L., Zhang, S., Han, L., Yang, D.-P., Hou, C., Liu, A., 2014. Electrochim. Acta 138, 109-114.

Han, M., Liu, S., Bao, J., Dai, Z., 2012. Biosens. Bioelectron. 31, 151-156.

Hayat, A., Andreescu, S., 2013. Anal. Chem. 85, 10028-10032.

Hrapovic, S., Luong, J.H.T., 2003. Anal. Chem. 75, 3308-3315.

Huang, J., Wang, X., Wang, Z., 2006. Nano Lett. 6, 2325-2331.

Huang, J., Zhan, G., Zheng, B., Sun, D., Lu, F., Lin, Y., Chen, H., Zheng, Z., Zheng, Y., Li, Q., 2011. Ind. Eng. Chem. Res. 50, 9095-9106.

Jiang, J., Li, Y., Liu, J., Huang, X., Yuan, C., Lou, X.W., 2012. Adv. Mater. 24, 5166-5180. Jones, M.R., Osberg, K.D., Macfarlane, R.J., Langille, M.R., Mirkin, C.A., 2011. Chem. Rev. 111, 3736-3827.

Katz, E., Willner, I., 2004. Angew. Chem. Int. Ed. 43, 6042-6108.

Knez, M., Bittner, A.M., Boes, F., Wege, C., Jeske, H., Maiß, E., Kern, K., 2003. Nano Lett. 3, 1079-1082.

Lang, X.Y., Fu, H.Y., Hou, C., Han, G.F., Yang, P., Liu, Y.B., Jiang, Q., 2013. Nat. Commun., 4.

Li, X., Fan, T., Zhou, H., Chow, S.K., Zhang, W., Zhang, D., Guo, Q., Ogawa, H., 2009. Adv. Funct. Mater. 19, 45-56.

Lin, Y., Ren, J., Qu, X., 2014. Acc. Chem. Res. 47, 1097-1105.

Liu, A., 2008. Biosens. Bioelectron. 24, 167-177.

Liu, A., Wei, M., Honma, I., Zhou, H., 2005. Anal. Chem. 77, 8068-8074.

Liu, A., Wei, M.D., Honma, I., Zhou, H., 2006. Adv. Funct. Mater. 16, 371-376.

Liu, H., Kameoka, J., Czaplewski, D.A., Craighead, H.G., 2004. Nano Lett. 4, 671-675.

Liu, Q., Zhang, T., Yu, L., Jia, N., Yang, D., 2013a. Analyst 138, 5559-5562.

Liu, S., Zhang, C., Yuan, L., Bao, J., Tu, W., Han, M., Dai, Z., 2013b. Part. Part. Syst. Charact. 30, 549-556.

Liu, X., Shi, L., Niu, W., Li, H., Xu, G., 2008. Biosens. Bioelectron. 23, 1887-1890.

Lu, W., Luo, Y., Chang, G., Sun, X., 2011. Biosens. Bioelectron. 26, 4791-4797.

Mai, L.Q., Yang, F., Zhao, Y.L., Xu, X., Xu, L., Luo, Y.Z., 2011. Nat. Commun. 2, 381. 
Meng, L., Jin, J., Yang, G., Lu, T., Zhang, H., Cai, C., 2009. Anal. Chem. 81, 7271-7280. Meyer, J., Hamwi, S., Kröger, M., Kowalsky, W., Riedl, T., Kahn, A., 2012. Adv. Mater 24, 5408-5427.

Nam, K.T., Kim, D.W., Yoo, P.J., Chiang, C.Y., Meethong, N., Hammond, P.T., Chiang, Y.M., Belcher, A.M., 2006. Science 312, 885-888.

Park, S., Boo, H., Chung, T.D., 2006. Anal. Chim. Acta 556, 46-57.

Park, S., Chung, T.D., Kim, H.C., 2003. Anal. Chem. 75, 3046-3049.

Rosi, N.L., Thaxton, C.S., Mirkin, C.A., 2004. Angew. Chem. 116, 5616-5619.

Ryu, J., Kim, K., Kim, H.S., Hahn, H.T., Lashmore, D., 2010. Biosens. Bioelectron. 26, 602-607.

Salimi, A., Hallaj, R., Soltanian, S., Mamkhezri, H., 2007. Anal. Chim. Acta 594, 24-31. Schnepp, Z., Yang, W., Antonietti, M., Giordano, C., 2010. Angew. Chem. Int. Ed. 122, 6714-6716.

Shimoni, E., Rav-Hon, O., Ohad, I., Brumfeld, V., Reich, Z., 2005. Plant Cell 17, 2580 2586.

Solanki, P.R., Kaushik, A., Agrawal, V.V., Malhotra, B.D., 2011. NPG Asia Mater. 3, 17 24.

Soleymani, L., Fang, Z., Sargent, E.H., Kelley, S.O., 2009. Nat. Nanotechnol. 4, $844-$ 848
Sotiropoulou, S., Sierra-Sastre, Y., Mark, S.S., Batt, C.A., 2008. Chem. Mater. 20, $821-$ 834.

Sun, C., Rajasekhara, S., Chen, Y., Goodenough, J.B., 2011. Chem. Commun. 47, $12852-12854$.

Vickers, D., Archer, L.A., Floyd-Smith, T., 2009. Colloids Surf. A: Physicochem. Eng. Asp. 348, 39-44.

Wei, H., Wang, E., 2013. Chem. Soc. Rev. 42, 6060-6093.

Xie, X., Li, Y., Liu, Z.Q., Haruta, M., Shen, W., 2009. Nature 458, 746-749.

Yang, D., Fan, T., Zhang, D., Zhu, J., Wang, Y., Du, B., Yan, Y., 2013. Chemistry - Eur. J. 19, 4742-4747.

Yang, Q., Atanasov, P., Wilkins, E., 1998. Sens. Actuators B: Chem. 46, 249-256.

Yu, X.Y., Meng, Q.Q., Luo, T., Jia, Y., Sun, B., Li, Q.X., Liu, J.H., Huang, X.J., 2013. Sci. Rep. 3, 2886.

Zamborini, F.P., Bao, L., Dasari, R., 2011. Anal. Chem. 84, 541-576.

Zheng, B., Kong, T., Jing, X., Odoom-Wubah, T., Li, X., Sun, D., Lu, F., Zheng, Y., Huang J., Li, Q., 2013. J. Colloid Interface Sci. 396, 138-145.

Zhou, H., Li, X., Fan, T., Osterloh, F.E., Ding, J., Sabio, E.M., Zhang, D., Guo, Q., 2010 Adv. Mater. 22, 951-956. 